\title{
Prediksi Penjualan Produk Promo PT. Unilever, Tbk Menggunakan Metode Fuzzy Time Series
}

\author{
Yehoshua $^{1)}$, Kustanto $^{2)}$, Retno Tri Vulandari ${ }^{3)}$ \\ 1) Program Studi Sistem Informasi, STMIK Sinar Nusantara \\ 2,3) Program Studi Teknik Informatika, STMIK Sinar Nusantara \\ 1)yehoshua.solideo@gmail.com; ${ }^{2}$ kustanto@sinus.ac.id; ${ }^{3)}$ retnotv@sinus.ac.id
}

\begin{abstract}
PT. Unilever is a multinational company headquartered in Rotterdam, the Netherlands (under the name Unilever N.V.), London, England (under the name Unilever pic.) And in Indonesia has a subsidiary, PT. Unilever, Tbk was established on December 5, 1933. Unilever produces food, drinks, cleaners, and also body care. Unilever is the third largest producer of household goods in the world, if based on the amount of revenue in 2012, behind $P \& G$ and Nestle. In forecasting products, it is often influenced by the sale of these products because there are also changes in sales for each period. Usually there is an increase in sales of these products which, among other things, is caused by price discounts, new products, one free one to buy promo, or a saving package from Unilever or from a rival company. Data collection method used by the author is a method of observation or directly observing the process of transmission, interview methods and literature study methods. While the method for processing data uses fuzzy time series algorithms, context diagrams, data flow diagrams, HIPO, relational diagram entities, data dictionary design, input design, output design, relation diagrams between tables, system implementation and testing. The method for implementation uses vb.net and Mysql. The results of this thesis are a system for calculating the forecasting amount of sales or sales of promo products for the following year. From this system, information on store data, item data, sales year history data, and forecasting data from fuzzy time series data will be displayed.. From rinso goods promotion data which have been calculated using fuzzy time series method which get MAPE value equal to 3,2\%, so sales data for category of goods will experience increase based on calculation equal to $3,2 \%$.
\end{abstract}

Keywords:PT Unilever Indonesia, Fuzzy Time Series, Information Systems

\section{PENDAHULUAN}

Promosi merupakan sebuah bagian terpenting dalam sebuah penjualan, dimana setiap promosi akan menghasilkan suatu produk akan laku dijual sehingga target dari penjualan tersebut dapat tercapai. Dalam penyusunan peramalan tersebut banyak didasarkan atas data yang relevan pada masa lalu. Sebelum melakukan peramalan harus diketahui terlebih dahulu apa sebenarnya persoalan dalam pengambilan keputusan itu. Peramalan yang baik mempunyai beberapa kriteria yang penting, antara lain akurasi, biaya,dan kemudahan. Dua metode yang sering digunakan untuk meramalkan suatu data yaitu analisis regresi dan metode runtun waktu (time series).

Berdasarkan atas produk promo yang dijalankan oleh PT Unilever, Tbk untuk mengetahui tingkat penjualan produk promosi maka penulis tertarik menggunakan metode fuzzy time series dimana penentuan intervalnya yang berbasis rata-rata penjualan diaplikasikan untuk meramalkan penjualan produk promosi di PT Unilever Tbk.

\section{TINJAUAN PUSTAKA}

Fuzzy time series adalah sebuah konsep baru yang diusulkan oleh Song dan Chissom berdasarkan teori fuzzy set dan konsep variabel linguistik dan aplikasinya oleh Zadeh. Fuzzy time series digunakan untuk menyelesaikan masalah peramalan yang mana data historis adalah nilai-nilai linguistik. Misalnya, dalam masalah peramalan, data historis tidak dalam bentuk angka real, namun berupa data linguistik. Dalam hal ini, tidak ada model time series konvensional yang dapat diterapkan, akan tetapi model fuzzy time series dapat diterapkan dengan lebih tepat. Pada penelitian sebelumnya, berdasarkan teori 
himpunan fuzzy, logika fuzzy dan penalaran perkiraan, Song dan Chissom mengajukan definisi fuzzy time series dan garis besar pemodelan dengan cara persamaan relasional fuzzy dan penalaran perkiraan. Kemudian oleh Chen (pada tahun 1996) diperkenalkan sebuah metode peramalan fuzzy time series menggunakan operasi arithmetic. Huarng (pada tahun 2001), menyajikan model heuristic untuk peramalan time series menggunakan heuristic increasing and decre-asing relations untuk memperbaiki peramalan enroll-ments dan exchange di Taiwan. Kemudian oleh Singh tahun 2007, diajukan algoritma komputasi sederhana, sehingga dapat mengurangi waktu untuk menghasilkan persamaan relational dengan menggunakan operasi komposisi maxmin yang kompleks dan mengurangi waktu untuk proses defuzzifikasi pada metode Song dan Chissom. Metode Singh dapat menyelesaikan masalah dalam mencari prosedur defuzzifikasi yang cocok untuk menghasilkan nilai output crisp dengan akurasi yang lebih baik. Perbedaan utama antara fuzzy time series dan konvensional time series yaitu pada nilai yang digunakan dalam peramalan, yang merupakan himpunan fuzzy dari bilangan-bilangan real atas himpunan semesta yang ditentukan. Himpunan fuzzy dapat diartikan sebagai suatu kelas bilangan dengan batasan yang samar.[1]

Langkah-langkah peramalan dengan metode yang diajukan oleh Reuy Chyn Tsaur [2] sebagai berikut :

1. Mengumpulkan data $\left(Y_{t}\right)$

2. Definisikan Universe of discourse $U$ berdasarkan jarak yang tersedia pada histori data runtun waktu, dengan aturan berdasarkan jarak yang tersedia pada histori data runtun waktu, dengan aturan $U=\left[D_{\min }-D_{1}, D_{\max }+D_{2}\right]$ dimana $D_{1}$ dan $D_{2}$ adalah nilai konstanta.

3. Menentukan interval I menggunakan metode average based length dengan langkah-langkah berikut :

a. Hitung selisih $D_{v t}, D_{v t-1}$ kemudian hitung rata-ratanya dengan rumus 2.1 .

$$
a v=\frac{\sum_{i=1}^{n}\left|D_{t^{-}} D_{t-1}\right|}{n-1}
$$

Dimana,

av adalah nilai rata-rata.

$\mathrm{n}$ adalah jumlah observasi.

Di adalah data ke i.

Di-1 adalah data ke i -1 . b. Bagi dua nilai rata-rata. Dengan rumus 2.2.

$$
B=\frac{a v}{2}
$$

Dimana B adalah basis.

c. Besar interval I adalah pembulatan nilai B kemudian basis ditentukan berdasarkan Tabel 1

Tabel 1. Tabel Pemetaan Basis

\begin{tabular}{|c|c|}
\hline Range & Base \\
\hline $0.1-1.0$ & 0.1 \\
\hline $1.1-10$ & 1 \\
\hline $11-100$ & 10 \\
\hline $101-1000$ & 100 \\
\hline $1001-10000$ & 1000 \\
\hline
\end{tabular}

4. Jumlah interval fuzzy diketahui dengan berdasarkan rumus 2.3 .

$$
m=\frac{D_{\max }+D_{1}-D_{\max }+D_{2}}{I} \ldots \ldots \ldots \text { ( }
$$

5. Tentukan himpunan fuzzy logical.

6. Tentukan fuzzy relationship.

7. Cari fuzzy logical relationship group.

8. Menghitung ramalan.

Langkah berikutnya untuk melakukan perhitungan perbedaan antara data asli dan data hasil peramalan adalah dengan metode MAPE (Means Absolute Presentage Error) pada rumus 2.4. Perbedaan tersebut diabsolutkan, kemudian dihitung ke dalam bentuk persentase terhadap data asli. Hasil persentase tersebut kemudian didapatkan nilai mean-nya. Suatu model mempunyai kinerja bagis jika nilai MAPE berada dibawah $10 \%$, dan mempunyai kinerja bagus jika nilai MAPE berada diantara $10 \%$ dan $20 \%$ [3].

$$
M A P E=
$$

$$
\frac{\sum\left(\left|D_{\text {aktual }}-D_{\text {peramalan }}\right|\right) \div D_{\text {aktual }}}{n} \times 100 \%
$$

Dari Penelitian yang dilakukan oleh Yopi Wahyu Purwanto dengan judul "Penerapan Fuzzy Time Series Untuk Memprediksi Tingkat Penjualan Batik Jember (Studi Kasus : Rumah Batik Rolla)", dengan hasil penelitian menghasilkan nilai prediksi secara periode dan memiliki jumlah rata-rata kenaikan angka 100 dan memiliki penurunan pola yang statis, serta memiliki tingkat Error MAPE sebesar $20 \%$, perbedaan dengan penelitian yang dilakukan penulis adalah nilai prediksi yang dilakukan adalah secara bulanan 
dan penulis memiliki pola kenaikan dan penurunan secara statis dan memiliki tingkat error MAPE sebesar 13\%. [4]

Dari Penelitian yang dilakukan oleh Normalita Fauziah dengan judul Peramalan menggunakan fuzzy time series Chen (Studi Kasus : Curah Hujan Kota Samarinda), dan hasil dari penelitian ini adalah berdasarkan data bulan Januari 2011-Mei 2016 diperoleh hasil peramalan untuk bulan Juni 2016 adalah $268 \mathrm{~mm}$. Peramalan curah hujan Kota Samarinda berdasarkan data bulan Januari 2013-Mei 2016 diperoleh hasil peramalan untuk bulan Juni 2016 adalah 287,5 mm. Untuk peramalan curah hujan Kota Samarinda berdasarkan data bulan Januari 2014-Mei 2016 diperoleh hasil peramalan untuk bulan Juni 2016 adalah adalah $300 \mathrm{~mm}$, perbedaan dari data yang digunakan penulis adalah penulis menggunakan data selama kurun waktu 5 tahun dan mempunyai kenaikan secara statis dan memiliki error MAPE sebesar $13 \%$. [5]

Dari Penelitian yang dilakukan oleh Rindy Aji dengan judul Sistem Pendukung Keputusan pemilihan prajurit berprestasi di KODIM 0728/WONOGIRI Menggunakan Weighting Product, dan hasil dari penelitian ini adalah berdasarkan data observasi dan. SPK Menentukan kriteria dan bobot keputusan. Bobot keputusan menunjukkan kepentingan relatif dari setiap kriteria, W $=(W 1, W 2, \ldots, W n \quad) . \quad$ Pada Weighting Productakan dicari bobot kepentingan dari setiapkriteria. Bobot untuk masing-masing kriteria tersebut yaitu $(\mathrm{W})=W 1=0.40$, $W 2=0.20, W 3=0.20, W 4=0.20$, perbedaan dari data yang digunakan penulis adalah penulis menggunakan data selama kurun waktu 5 tahun dan mempunyai kenaikan secara statis dan memiliki error MAPE sebesar $13 \%$.[6]

Dari Penelitian yang dilakukan oleh Malim Muhammad dengan judul "Sebaran dan Peramalan Mahasiswa Baru Pendidikan Matematika Universitas Muhammadiyah Purwokerto dengan Metode Time Invariant Fuzzy Time Series". Dalam hal ini baik program studi Pendidikan Matematika dan Pendidikan Guru SD dan pihak Universitas dapat mengambil kebijakan yang tepat terkait penerimaan mahasiswa baru berdasarkan sebaran dan prediksi tersebut di atas. Pada peramalan pendaftaran dengan 6 himpunan fuzzy, pada tahun 2016-2020 diramalkan jumlah mahasiswa pendidikan matematika dan PGSD Universitas Muhammadiyah Purwokerto sebesar 389, 459, 427, 497, dan 465 mahasiswa, dengan error ramalan 47,5 $\%$.[7]

\section{METODE PENELITIAN}

Salah satu masalah yang terpenting dalam penelitian adalah melalui metode tertentu untuk memecahkan suatu masalah yang diperoleh dengan tujuan agar mendapat hasil yang dapat dipertanggung jawabkan. Adapun langkah-langkah dalam teknik pengumpulan data suatu penelitian adalah sebagai berikut :

a. Metode Kuisioner

Kuisioner dilakukan di perusahaan dengan melakukan penyebaran kuisioner kepada 30 petugas, dimana terdapat 8 pertanyaan, dari hasil tersebut didapatkan rata-rata adalah $70 \%$ dari hasil kuisioner tersebut.

b. Metode Wawancara

Wawancara dilakukan ke bagian penjualan dimana didapatkan data penjualan, dari tahun 2013 sampai dengan tahun 2017 dimana ditunjukkan pada tabel 1. Tabel 1 menunjukkan data penjualan yang dilakukan oleh PT Unilever dalam jurum waktu 2013 sampai 2017 dimana terdapat 3 jenis barang yaitu rinso, sunlight dan lifeboy.

\section{HASIL DAN PEMBAHASAN 1. Studi KasusMetode Fuzzy Time Series Langkah 1. Input data}

Data penjualan barang dengan kategori barang-barang promosi antara tahun 2013 sampai dengan tahun 2017 akan diramal dengan fuzzy time series. Data aktual penjualan ditunjukkan pada Tabel 1 .

Langkah 2. Definisikan universe of discourse

Nilai minimal dan maksimal dari data aktual penjualan barang kategori barang promo adalah 13244 dan 21367. Berdasarkan nilai-nilai tersebut maka universe of discourse $U$ dapat didefinisikan sebagai $U=$ [13244,21367].

Langkah 3. Menghitung interval dan himpunan fuzzy dengan nilai absolute

Tabel 2. Tabel Nilai Absolute

\begin{tabular}{|r|r|r|}
\hline Tahun & $\begin{array}{c}\text { Data } \\
\text { Penjualan }\end{array}$ & $\begin{array}{c}\text { Selisih Absolute } \\
\text { Data }\end{array}$ \\
\hline 2013 & 21367 & \\
\hline
\end{tabular}




\begin{tabular}{|r|r|r|}
2014 & 13244 & 8123 \\
\hline 2015 & 19432 & 6188 \\
\hline 2016 & 15325 & 4107 \\
\hline 2017 & 19568 & 4243 \\
\hline Total & $\mathbf{8 8 9 3 6}$ & $\mathbf{2 2 6 6 1}$ \\
\hline
\end{tabular}

Menentukan Rata-Rata Dengan rumus :

$$
\begin{aligned}
& \text { Average }=\frac{\sum\left|\mathrm{x}_{\mathrm{t}+1-} \mathrm{x}_{\mathrm{t}}\right|}{\mathrm{n}} \ldots \ldots \ldots \ldots \ldots . . . . . \\
& \text { Average }=\frac{22661}{5}=4532
\end{aligned}
$$

Setelah diketahui average dari nilai absolute selanjutnya mencari rata-rata selisih dengan rumus sebagai berikut :

Rata-Rata Selisih $=\frac{\operatorname{Avrg}(\text { Absolute })}{2} \ldots \ldots . .(2)$

Rata-Rata Selisih $=\frac{4532}{2}=2266$

yang dirujuk menjadi basis 1000 .

Setelah mengetahui nilai rata-rata selisih selanjutnya mencari basis interval dari nilai tersebut dengan rumus :

jumlah interval efektif $=\frac{\left(\mathrm{D}_{\max }-\mathrm{D}_{\min }\right)}{\text { basis interval }}$

jumlah interval efektif $=\frac{(13244-21367)}{1000}=9$

sehingga jumlah interval efektifnya adalah 9 dengan jangkauan basis 1000 Selanjutnya menentukan interval efektif dengan himpunan fuzzy, dimana mengambil angka minimal sebagai batas bawah dengan nilai [13244] dan untuk mendapatkan batas atas dengan menambah nilai batas bawah ditambah 1000 menjadi [14244] dimana 1000 sebagai jangkauan basisnya yang ditunjukkan pada tabel 2.

Tabel 3. Himpunan Fuzzy

\begin{tabular}{|c|c|c|}
\hline Batas bawah & Batas atas & $\begin{array}{c}\text { Interval } \\
(\mathbf{u})\end{array}$ \\
\hline 13244 & 14244 & 1 \\
\hline 14244 & 15244 & 2 \\
\hline 15244 & 16244 & 3 \\
\hline 16244 & 17244 & 4 \\
\hline 17244 & 18244 & 5 \\
\hline 18244 & 19244 & 6 \\
\hline 19244 & 20244 & 7 \\
\hline 20244 & 21244 & 8 \\
\hline 21244 & 22244 & 9 \\
\hline
\end{tabular}

Selanjutnya menentukan nilai tengah dari interval $U$ untuk menentukan nilai $A_{1} \ldots n$ yang digunakan untuk peramalan, dimana dambil contoh U1 sebagai nilai A1 yang bernilai [13244,14244] dengan rata-rata bernilai A1 13744 sebagai hasil fuzzykasinya, berikut hasilnya ditunjukkan pada tabel 3 .

Tabel 4. Fuzzykasi

\begin{tabular}{|l|l|}
\hline \multicolumn{1}{|c|}{ Nilai lingustik } & \multicolumn{1}{c|}{ Fuzzifikasi } \\
\hline A1 & 13744 \\
\hline A2 & 14744 \\
\hline A3 & 15744 \\
\hline A4 & 16744 \\
\hline A5 & 17744 \\
\hline A6 & 18744 \\
\hline A7 & 19744 \\
\hline A8 & 20744 \\
\hline A9 & 21744 \\
\hline
\end{tabular}

Langkah 4.Fuzzifikasi data actual

Berdasarkan himpunan fuzzy maka diperoleh fuzzifikasi, sebagai contoh data penjualan 21367 dengan fuzzykasi hasil peramalan A1 dan mendapat nilai peramalan sebesar 13744, untuk fuzzykasi data actual ditunjukkan pada Tabel 6.

Tabel 5. Fuzzyfikasi data actual

\begin{tabular}{|l|l|l|l|}
\hline $\begin{array}{l}\text { Data } \\
\text { Penjualan }\end{array}$ & $\begin{array}{l}\text { Hasil } \\
\text { Akhir } \\
\text { Prediksi }\end{array}$ & $\begin{array}{l}\text { Data } \\
\text { Prediksi }\end{array}$ & $\left(\left|F_{a}-F_{p}\right|\right)$ \\
\hline 21367 & A9 & 0 & 0 \\
\hline 13244 & A1 & 13744 & 0.04 \\
\hline 19432 & A7 & 19744 & 0.02 \\
\hline 15325 & A3 & 15744 & 0.03 \\
\hline 19568 & A7 & 19744 & 0.07 \\
\hline 0 & - & 15744 & 0.16 \\
\hline
\end{tabular}

Langkah 5.Menghitung Nilai MAPE

Penghitungan nilai MAPE setelah melakukan perhitungan dengan fuzzy time series berikut rumusnya :

$$
\begin{aligned}
& \text { MAPE }=\frac{\sum\left(\left|\mathrm{F}_{\mathrm{a}}-\mathrm{F}_{\mathrm{p}}\right|\right) / \mathrm{F}_{\mathrm{a}}}{\mathrm{n}} * 100 . \\
& \begin{array}{l}
\text { MAPE }=\frac{(0.16)}{5} * 100 \\
=3 \%
\end{array}=0,32 * 10 \%
\end{aligned}
$$

Berdasarkan data nilai MAPE maka terdapat 3\% nilai kesalahan, dimana aplikasi memiliki hasil perbedaan dengan sistem sebesar 3\%.

Diagram Konteks 
Diagram konteks menggambarkan sitem prediksi penjualan barang promosi yang akan dikembangkan oleh penulis, berikut diagram konteks:

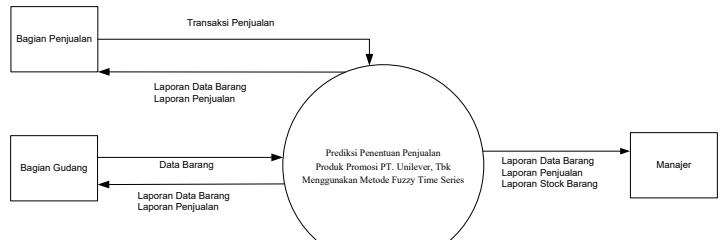

Gambar 1. Diagram Konteks

Berdasarkan diagram konteks di gambar 1 menggambarkan sistem yang dilakukan oleh Bagian Penjualan menginput data transaksi dan mendapatkan laporan data barang, laporan penjualan dan prediksi barang, untuk bagian gudang dan manajer mendapatkan laporan data barang, penjualan dan prediksi barang.

\section{Diagram Alir Data}

Diagram alir data adalah penggambaran sistem secara komputerisasi yang melibatkan kesatuan luar.

Diagram Alir Data Level 0

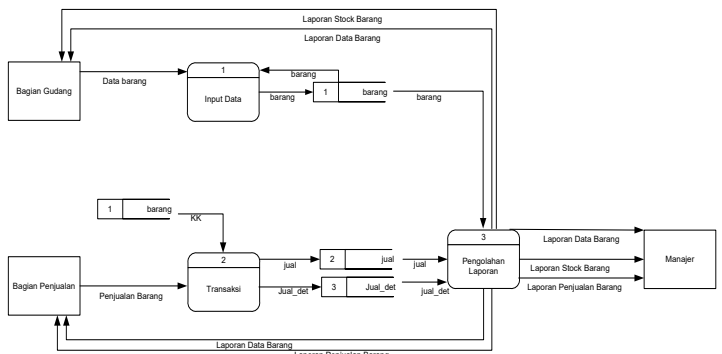

Gambar 2. Diagram Alir Data Level 0

Diagram alir data level 0 menggambarkan sistem input data dimana disimpan dalam database, input data barang disimpan dalam data barang dan transaksi disimpan pada tabel jual dan jual det.

\section{Diagram Alir Data Level 1}

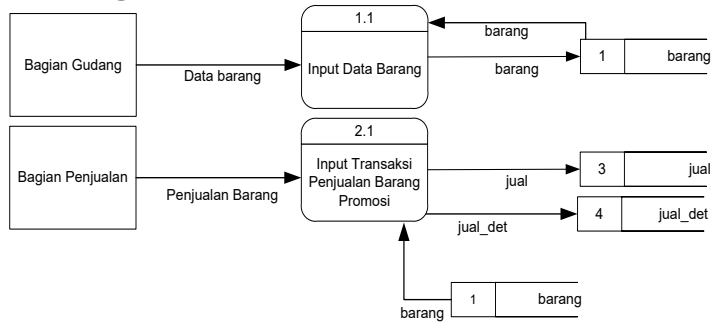

Gambar 3. Diagram Alir Data Proses 1

Diagram Alir data proses 1 menggambarkan proses input data barang dimana disimpan dalam tabel barang dan data store disimpan pada tabel store.

\section{Diagram Alir Data Level 2}

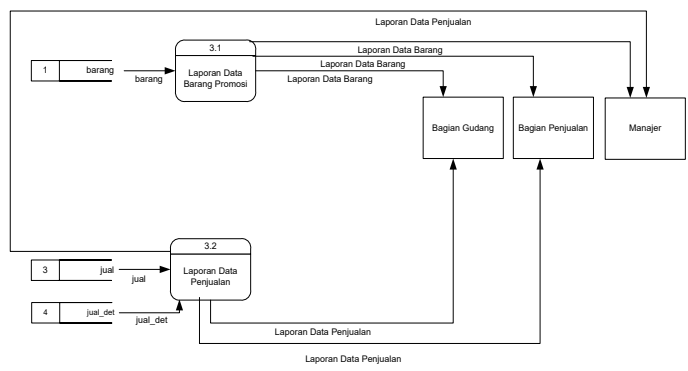

Gambar 4. Diagram Alir Data Proses 2

Diagram Alir data proses 2 menggambarkan proses transaksi penjualan dan prediksi dimana disimpan dalam tabel jual, jual_det dan rekap jual, sedangkan prediksi disimpan dalam tabel hasil_prediksi.

\section{Diagram Entitas Relasi}

Diagram ini menghubungkan antar entitas yang terlibat dalam PT Unilever Indonesia dan setiap aplikasi yang dijalankan dilakukan oleh bagian penjualan dimana setiap transaksi penjualan dilakukan oleh bagian penjualan.

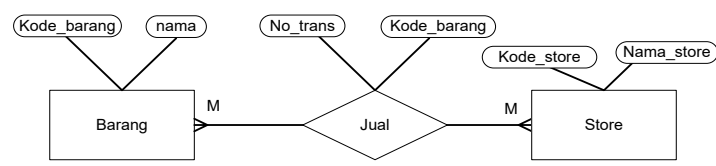

Gambar 6. Diagram Entitas Relasi Awal

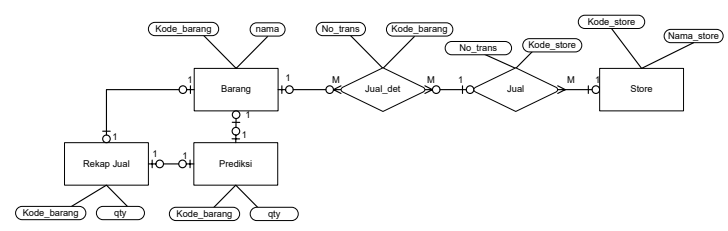

Gambar 7. Normalisasi Databases

Berdasarkan gambar 7 relasi yang terjadi adalah sebagai berikut :

1. Barang dijual kepada toko-toko merupakan relasi antara entitas Barang dan jual serta jual_det dimana satu barang bisa dijual lebih dari satu toko, sehingga kardinalitasnya adalah one to many untuk barang dengan relasi jualdet dan kardinalitas many to one untuk jual_det dengan jual dan kardinalitas many to one untuk jual dengan store.

2. Barang yang sudah terjual direkap dalam tabel rekap_jual yang nantinya akan digunakan dalam melakukan prediksi 
penjualan barang, dimana merupakan relasi antara barang, jual_det, dan jual dengan tabel rekap_jual, dimana kardinalitasnya antara barang dan rekap_jual adalah one to one dimana satu barang berelasi satu barang dengan satu barang.

Barang yang sudah dilakukan penjualan dan direkap di tabel rekap jual, lalu dilakukan prediksi dengan metode double exponential smoothing, dimana rekap_jual relasi dengan prediksi dengan kardinalitas one to one dengan tabel barang, dimana setiap barang per item akan dilakukan prediksi masing-masing berdasarkan data penjualannya.

\section{Relasi Antar Tabel}

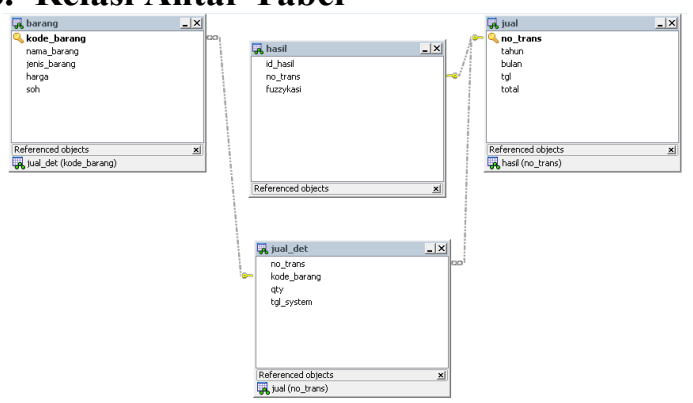

Gambar 8. Relasi Antar Tabel

Relasi antar tabel menggambarkan sistem relasi antara tabel dimana tabel barang relasi dengan tabel jual detail, rekap jual dan hasil prediksi dengan kondisi many to one. Dan Tabel Petugas dihubungkan dengan tabel jual dengan kondisi many to one, dan tabel store dengan tabel jual dengan kondisi many to one. Sedangkan prediksi mengambil kondisi dari rekap jual dengan kondisi many to many.

\section{Desain Teknologi}

Desain teknologi diperlukan sebagai langkah untuk menentukan kebutuhan perangkat keras (hardware) dan kebutuhan perangkat lunak (software). Kedua perangkat tersebut digunakan sebagai penunjang dalam penggunaan Prediksi Penjualan Pada PT. Unilever Indonesia dengan Metode Fuzzy Time Series. Untuk perhitungan jumlah waktu tersedia adalah satu bulan kerja dihitung 30 hari. Kerja setiap harinya 8 jam, istirahat 1 jam, dikalikan 60 menit. Jadi waktu yang tersedia : $7 \times 60 \times 30$ hari $=$ 12.600 menit.
Tabel 6. Kapasitas File Penyimpanan

\begin{tabular}{|c|c|c|c|c|c|}
\hline $\mathrm{N}$ & Nama File & $\begin{array}{l}\text { Panjang } \\
\text { Reco } \\
\text { rd }\end{array}$ & $\begin{array}{c}\text { Volum } \\
\mathrm{e}\end{array}$ & $\begin{array}{c}\text { Kejadia } \\
\mathrm{n}\end{array}$ & $\begin{array}{r}\text { Kapasitas } \\
\text { (byt } \\
\text { e) }\end{array}$ \\
\hline 1 & $\begin{array}{r}\text { Input Data } \\
\text { Petugas }\end{array}$ & 82 & 150 & $1 \mathrm{kali}$ & 12300 \\
\hline 2 & $\begin{array}{c}\text { Input Data } \\
\text { Barang } \\
\end{array}$ & 108 & 200 & $1 \mathrm{kali}$ & 21600 \\
\hline 3 & $\begin{array}{c}\text { Input Data } \\
\text { Penjual } \\
\text { an } \\
\end{array}$ & 138 & 250 & $1 \mathrm{kali}$ & 34500 \\
\hline \multicolumn{5}{|c|}{ Jumlah } & 188400 \\
\hline
\end{tabular}

Kapasitas dalam file index adalah $50 \%$ dari database yang dibuat yaitu 184400 Sedangkan kapasitas file cadangan adalah kapasitas dari file database ditambah kapasitas file index yaitu 92200.

\section{Implementasi Sistem}

a) Prediksi Penjualan

Prediksi penjualan digunakan untuk melaporkan data prediksi penjualan. Berikut tampilannya :

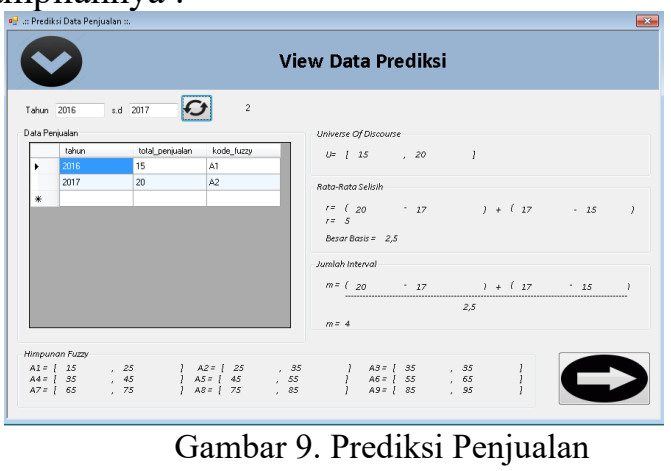

b) Laporan Data Penjualan

Laporan data penjualan digunakan untuk melaporkan data penjualan. Berikut tampilan laporan data penjualan:

\begin{tabular}{|c|c|c|c|}
\hline 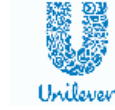 & & \multicolumn{2}{|c|}{$\begin{array}{l}\text { PT UNILEVER TBK } \\
\text { LAPORAN DATA PENJUALAN }\end{array}$} \\
\hline No Transaksi & Kode Store & Nama Store & Total \\
\hline$\overline{\Gamma-01}$ & S-01 & ALFAMART & 20,00 \\
\hline$\Gamma-02$ & S-01 & ALFAMART & 15,00 \\
\hline T-03 & $\mathrm{S}-02$ & INDOMARET & 0,00 \\
\hline T-04 & S-03 & LION & 30,00 \\
\hline
\end{tabular}

Gambar 13. Laporan Data Penjualan

\section{Pengujian Sistem}

Pengujian dengan menggunakan metode black box ini dilakukan dengan mengevaluasi cara kerja sistem yang telah dibuat.

1) Pengujian Untuk Fungsional Login Pengujian Fungsional Login digunakan untuk menginput data login yang digunakan untuk masuk ke system. 
Menggunakan data login dan berhasil digunakan.

2) Pengujian Untuk Fungsional Master Pengujian Fungsional Master dengan menginputkan data barang, dan data supplier dimana diharapkan hasil yang diinputkan masuk ke dalam tabel dalam database yang meliputi tabel sparepart untuk master data sparepart. Dari pengujian fungsional master tersebut dimana data dapat disimpan di data master.

3) Pengujian Untuk Fungsional Transaksi Pengujian Fungsional Transaksi dimana melakukan input transaksi penjualan dan dimasukkan ke dalam tabel jual dan jual_det yang digunakan dalam transaksi untuk menentukan prediksi penjualan dengan menggunakan metode double exponential smoothing, sehingga saat melakukan dapat diketahui tingkat prediksi penjualan pada tahun selanjutnya. Dimana data transaksi dapat disimpan di tabel transaksi penjualan dan prediksi.

4) Pengujian Untuk Fungional Prediksi Penjualan dengan Fuzzy Time Series Pengujia Fungisional Prediksi digunakan untuk memprediksikan data penjualan barang dimana agar diketahui penjualan di tahun selanjutnya. Dimana menggunakan tabel transaksi penjualan yang disimpan di tabel prediksi untuk menghasilkan data prediksi berhasil ditampilkan.

5) Pengujian Untuk Fungsional Report Pengujian Fungsional Report untuk menghasilkan report dari database dimana menampilkan data master sparepart, data transaksi penjualan dan semua laporan berhasil ditampilkan. Dimana laporan berhasil ditampilkan.

\section{KESIMPULAN}

Berdasarkan hasil penelitian bahwa, data promosi barang rinso yang telah dihitung menggunakan metode fuzzy time series dimana mendapatkan nilai MAPE sebesar 3\%, sehingga data penjualan untuk kategori barang tersebut akan mengalami kenaikan berdasarkan perhitungan sebesar 3\%.

\section{REFERENSI}

K. Nugroho, "Model Analisis Prediksi
Menggunakan Metode Fuzzy Time Series," Infokam, vol. 12, no. 1, pp. 46-50, 2016.

S. S. Berutu, "Peramalan Penjualan Dengan Metode Fuzzy Time Series Ruey Chyn Tsaur," Universitas Diponegoro Semarang, 2013.

P. Linda, M. Situmorang, and G. Tarigan, "Peramalan Penjualan Produksi Teh 2014 Dengan Metode Arima BoxJenkins," Saintia Mat., vol. 02, no. 03, pp. 253-266, 2014.

Y. W. Purwanto, "Penerapan Metode Fuzzy Time Series Untuk Memprediksi Tingkat Penjualan Batik Jember," Digit. Univ. Jember, vol. 1, pp. 7-9, 2016.

N. Fauziah, S. Wahyuningsih, Y. N. Nasution, E. Smoothing, and N. Network, "Peramalan Mengunakan Fuzzy Time Series Chen ( Studi Kasus: Curah Hujan Kota Samarinda )," Statistika, vol. 4, no. 2, 2016.

R. A. S. Pratama, Kustanto, and S. H. Fitriasih, "Sistem Pendukung Keputusan Pemilihan Prajurit Berprestasi di Kodim 0728/Wonogiri Menggunakan Metode Weighting Product," J. TIKomSin, vol. 5, no. 1, pp. 1-6, 2017.

M. Muhammad, "Sebaran Dan Peramalan Mahasiswa Baru Pendidikan Matematika Universitas Muhammadiyah Purwokerto Dengan Metode Time Invariant Fuzzy Time Series," Mat. J., vol. III No. 2, no. 345, pp. 48-58, 2016. 